\title{
Effect of retinoic acid on mucin gene expression in rat airways in vitro
}

\author{
Brigitta MANNA, ${ }^{*}$ Maxine LUND, ${ }^{\star}$ Patrick ASHBAUGH, $\dagger$ Bernard KAUFMAN $\ddagger$ and Sambhu N. BHATTACHARYYA $§$ \\ *Department of Clinical Investigation, †Electron Microscopy Section, William Beaumont Army Medical Center, El Paso, TX 79920-5001, U.S.A., \\ and $\ddagger$ Department of Biochemistry, Duke University Medical Center, Durham, NC, U.S.A.
}

Ultrastructural examination of rat tracheal explants at various times of culture in a serum-free and hormone-supplemented medium containing retinoic acid showed that the cytological characteristics of the epithelium were well preserved for at least $192 \mathrm{~h}$. Hybridization analyses for mucin core protein mRNA in the explants were performed with a 30-base oligonucleotide probe, the design of which was based on the tandem repeat sequence of the rat intestine mucin core protein. The probe reacted with total RNA prepared from trachea, intestine and colon, but not with total RNA obtained from liver or alveolar region of the lung. Type-I keratin expression was observed in the explant grown at different periods of time in a medium with and without retinoic acid. The hybridization probe gave a prominent reaction with RNA preparations obtained from tracheal explants incubated for as long as $192 \mathrm{~h}$ in a medium containing retinoic acid. In the absence of retinoic acid, however, the mucin message was evident at the $24 \mathrm{~h}$ time point but thereafter decreased to barely detectable levels. When retinoic acid was added at $96 \mathrm{~h}$ to the latter cultures, the mucin mRNA was prominent again after additional incubation for 24 and $48 \mathrm{~h}$. Northern-blot analyses of tracheal RNA showed a diffuse band at approx. $7.5 \mathrm{~kb}$. Addition of a variety of chemical and pharmacological agents to explants cultured in the presence of retinoic acid had no dramatic induction or inhibitory effects on the mucin mRNA. Only the steroid prednisolone had a reproducible inhibitory effect.

\section{INTRODUCTION}

Bronchial mucus glycoproteins (mucins) are localized on the apical surface of the mucus membrane where they function in the mucociliator-escalator systems which protect the airways from microscopic particles and infections. Accumulation of mucus resulting in bronchial obstruction is one of the principal problems in patients suffering from upper airway respiratory diseases, such as asthma, chronic bronchitis, cystic fibrosis and acute pneumonia. The precise mechanism(s) involved in the accumulation of mucus in these diseases is not known, but all evidence points to overproduction rather than defective clearance by the mucociliary aspects of the system.

It has been reported (Harris et al., 1977; Wu, 1986; Marchok and Wasilenko, 1986; Rearick et al., 1987) that actively secreting tracheal epithelium, in which the incorporation of radiolabelled saccharides was used as a measure of mucin synthesis and secretion, could be maintained for several weeks in a serum-free medium supplemented with growth factors and retinoids. Although retinoids, i.e. vitamin A and its natural and synthetic derivatives, control epithelial cell differentiation and have definite influence on the production of mucins, the site(s) of regulation has not been defined, i.e. whether the effect is at the transcriptional phase or in the subsequent phases of translation and posttranslational glycosylation. Studies presented in this report were designed to address the issue of whether retinoic acid influences mucin gene expression in rat tracheal epithelium. Recently, we observed (Bhattacharyya et al., 1992) that rabbit tracheal epithelial cells could be maintained in a serum-free and hormonesupplemented medium containing retinoic acid for a long period of time and that the cells expressed mucin gene when total RNA isolated from these cells was hybridized with a 30-base oligonucleotide probe derived from a rat intestine peptide tandem repeat sequence, RMUC 176 (Gum et al., 1991). However, in the absence of retinoic acid in the culture medium, the cells did not grow or produce mucins.
In view of the above findings that the production of mucins is regulated by retinoic acid, we decided to examine the effect of this agent on the expression of mucin gene in rat tracheal organ culture system in a serum-free and hormone-supplemented medium.

\section{EXPERIMENTAL}

\section{Materials}

All chemicals were of the highest purity available. The following materials were obtained from different commercial sources: epidermal growth factor and endothelial cell growth supplement from Collaborative Research Inc., Bedford, MA, U.S.A.; ELink Plus oligonucleotide-labelling kit from Cambridge Research Biochemicals, Wilmington, DE, U.S.A.; RNA-isolation kit, RNAase inhibitor, rat $\beta$-actin probe and custom synthesized 5'amino oligonucleotide probes from Clontech Laboratories Inc., Palo Alto, CA, U.S.A.; Hybond membrane from Amersham Corporation, Arlington Heights, IL, U.S.A.; Dulbecco's modified Eagle's medium/F-12 Ham's medium, minimum essential medium, insulin, transferrin, 5-azacytidine, atropine, methacholine, histamine, phenylephrine, retinoic acid, isoprenaline, prednisolone, 8-bromocyclic AMP, actinomycin D and $\alpha$-amanitin, agarose, ethidium bromide, Ficoll, poly(vinylpyrrolidone), BSA, SDS, Mops and different molecular biology products from Sigma Chemical Company, St. Louis, MO, U.S.A.; agarose-gel electrophoresis apparatus from International Biotechnologies Inc., New Haven, CT, U.S.A., and dot-blot apparatus from Bio-Rad Laboratories, Richmond, CA, U.S.A. RNA molecular-mass markers were obtained from Bethesda Research Laboratory, MD, U.S.A.

\section{Organ culture}

Tracheal ring organ cultures were prepared from certified virusfree Sprague-Dawley rats (150-200 g; Hilltop Laboratories,

$\S$ To whom correspondence should be addressed. 
Scottdale, PA, U.S.A.). Tracheas were excised, trimmed, washed in minimal essential medium, and cut into rings (1-2 mm). Rings from two tracheas ( $225 \mathrm{mg}$ wet weight) were placed on $60 \mathrm{~mm} \times 15 \mathrm{~mm}$ dishes and maintained in $6 \mathrm{ml}$ of Dulbecco's modified Eagle's medium/F-12 Ham's medium supplemented with the following: insulin $(25 \mathrm{ng} / \mathrm{ml})$, transferrin $(5 \mu \mathrm{g} / \mathrm{ml})$, epidermal growth factor $(25 \mathrm{ng} / \mathrm{ml})$, hydrocortisone $(1 \mu \mathrm{mol} / \mathrm{ml})$, endothelial cell growth supplement $(0.015 \%)$, penicillin and streptomycin $(100 \mu \mathrm{g} / \mathrm{ml})$, gentamicin $(50 \mu \mathrm{g} / \mathrm{ml})$, fungizone $(50 \mu \mathrm{g} / \mathrm{ml})$ and retinoic acid $(0.1 \mu \mathrm{M})(\mathrm{Wu}, 1986$; Rearick et al., 1987; Bhattacharyya et al., 1992). The cultures were incubated at $37^{\circ} \mathrm{C}$ in a humidified incubator containing air $/ \mathrm{CO}_{2}$ (19:1). During the course of the culture, the medium was changed every $48 \mathrm{~h}$. The composition of the culture medium was the same when studies were performed without retinoic acid.

\section{Isolation of RNA}

Total RNA was isolated from rat trachea ( $225 \mathrm{mg}$ wet weight), alveolar region of the lung ( $225 \mathrm{mg}$ wet weight), intestine (225 mg wet weight), colon (225 mg wet weight) and liver (225 mg wet weight) using Clontech's RNA-isolation kit, which utilizes a guanidine thiocyanate/phenol/chloroform single-step extraction procedure (Chomczynski and Sacchi, 1987) as described previously (Bhattacharyya et al., 1992). In brief, the tissues were suspended in $2.0 \mathrm{ml}$ of detergent containing $4 \mathrm{M}$ guanidine thiocyanate (Clontech) and homogenized at $0{ }^{\circ} \mathrm{C}$ with a Polytron homogenizer (setting 7 for $30 \mathrm{~s}$ ). The homogenate was mixed with $0.2 \mathrm{ml}$ of $2 \mathrm{M}$ sodium acetate $(\mathrm{pH} 4.0), 2.0 \mathrm{ml}$ of phenol (water-saturated) and $0.4 \mathrm{ml}$ of chloroform/3-methylbutan-1-ol $(49: 1, \mathrm{v} / \mathrm{v})$. The mixture was shaken vigorously for $10 \mathrm{~s}$, cooled in ice for $15 \mathrm{~min}$ and centrifuged in the cold at $5000 \mathrm{~g}(9000 \mathrm{rev}$./ $\mathrm{min}$ ) for $20 \mathrm{~min}$. The aqueous phase was transferred to another centrifuge tube. An equal volume of $100 \%$ propan-2-ol (cold) was added to the aqueous phase and RNA was precipitated at $-20^{\circ} \mathrm{C}$ for $1 \mathrm{~h}$. The solution was centrifuged in the cold at $6500 \mathrm{~g}(10000 \mathrm{rev} . / \mathrm{min})$ for $20 \mathrm{~min}$. The precipitate was transferred to a microcentrifuge tube and dissolved in $0.3 \mathrm{ml}$ of detergent containing $4 \mathrm{M}$ guanidine thiocyanate. An equal volume of $100 \%$ propan-2-ol (cold) was added to the solution and RNA was precipitated again at $-20^{\circ} \mathrm{C}$ for $1 \mathrm{~h}$. The precipitate was collected by centrifugation at $6500 \mathrm{~g}$, dried under vacuum and dissolved in $25 \mu \mathrm{l}$ of Tris/EDTA buffer and stored as an ethanol precipitate at $-70^{\circ} \mathrm{C}$ after addition of $0.1 \mathrm{vol}$. of $3 \mathrm{M}$ sodium acetate and $2.5-3.0$ vol. of $100 \%$ ethanol.

The precipitated RNA was collected by centrifugation at $5000 \mathrm{~g}$, dried under a vacuum and rehydrated with a minimum volume of Tris/EDTA buffer containing RNAase inhibitor. RNA was quantified by measuring absorbance at $260 \mathrm{~nm}$. A portion (5-10 $\mu \mathrm{g}$ in a 1-5 $\mu \mathrm{l}$ volume) of this preparation was run on a formaldehyde/agarose $(1 \%)$ gel in $1 \times$ Mops buffer (Davis et al., 1986). The electrophoresis was conducted at $50 \mathrm{~V}$ for approx. $1 \mathrm{~h}$, or until the dye front reached almost the end of the gel. RNA molecular-mass markers were run in the same gel as the RNA from rat tissue. The gel was stained with ethidium bromide. RNA was transferred to the Hybond membrane from the gel for Northern-blot hybridization as described previously (Davis et al., 1986). The membrane was dried under vacuum at $80^{\circ} \mathrm{C}$ for $2 \mathrm{~h}$.

Direct transfer of total RNA $(0.4-1.0 \mu \mathrm{g})$ to spots on the Hybond membrane was made in a dot-blot apparatus, and the membrane was dried as described above.

An amino-linked antisense 30-mer oligonucleotide to rat intestine mucin protein tandem repeat sequence, RMUC 176,
TTTPDVTTTP (5'-X AGGGGTGGTGGTCACATCAGGAGTGGTGGT-3', where $X=$ amine) (Gum et al., 1991) was synthesized and conjugated to alkaline phosphatase using an E-link Plus oligonucleotide-labelling kit. The membrane was hybridized with $1.0 \mathrm{nM}$ conjugated probe by the procedure given with the E-Link Plus oligonucleotide-labelling kit and reported previously (Bhattacharyya et al., 1992). After hybridization, the membrane was stained with Lumi-Phos solution, placed between two acetate sheets and exposed to Kodak XAR-5 film for $3 \mathrm{~h}$ at $37^{\circ} \mathrm{C}$. All experiments were performed with the same concentration of probe $(1.0 \mathrm{nM})$ under identical conditions. Hybridization with E-linked rat $\beta$-actin probe was by the same procedure as just described.

An amino-linked antisense 30 -mer oligonucleotide to mouse type-I keratin protein sequence, GGDQSSKGPR $\left(5^{\prime}-\mathrm{X}\right.$ TGGTCCTTTAGATGATTGGTCGCCGCCACC-3', where $\mathrm{X}=$ amine) (Krieg et al., 1985), was synthesized and conjugated to alkaline phosphatase using the E-link Plus oligonucleotidelabelling kit. The membrane was hybridized with $1.0 \mathrm{nM}$ conjugated probe as described above.

\section{Effect of retinoic acid and pharmacological agents}

Time-dependent mucin gene expression with or without retinoic acid $(0.1 \mu \mathrm{mol} / \mathrm{ml})$ was determined by incubating tracheal rings from two tracheas $(225 \mathrm{mg}$ wet weight) in $6.0 \mathrm{ml}$ of culture medium for $24,48,96,144$ and $192 \mathrm{~h}$ under the conditions described above. In order to examine the effect of retinoic acid $(0.1 \mu \mathrm{mol} / \mathrm{ml})$ on mucin mRNA content in tracheal culture grown in $6.0 \mathrm{ml}$ of medium without retinoic acid, tracheal rings (225 mg wet weight) were initially maintained in a retinoic aciddeficient medium for $96 \mathrm{~h}$ before addition of the compound, and the incubation was continued for an additional 24 and $48 \mathrm{~h}$. Duplicates and controls were run under the same conditions. At the end of the incubation, total RNA was isolated from tissues as described above. In order to determine the effect of different pharmacological agents on mucin gene expression, tracheal rings (225 mg wet weight) were initially maintained in $6.0 \mathrm{ml}$ of culture medium containing retinoic acid for $96 \mathrm{~h}$ before addition of different reagents and incubation was continued for another $48 \mathrm{~h}$. When the effect of the steroid, prednisolone, on mucin gene expression was examined, hydrocortisone was omitted from the culture medium. Total RNA was isolated from tissues as described above.

\section{Electron microscopy}

The tissues prepared for electron microscopy were fixed in $3.5 \%$ (w/v) glutaraldehyde, postfixed with $1 \%$ osmium tetroxide, and embedded in epoxy resin. Ultrathin sections were stained with uranyl acetate and lead acetate before examination in a transmission electron microscope (Bhattacharyya et al., 1992).

\section{RESULTS}

Rat tracheal organ cultures were maintained in a serum-free hormone-supplemented medium for 0-8 days. Transmissionelectron-microscopic studies on rat trachea at $0 \mathrm{~h}$ (baseline) indicated normal epithelium with microvilli and occasional electron-dense secretory granules localized in the apical region of the cell (Figure 1). When cultured in the same medium containing retinoic acid for several days, the explants still exhibited wellpreserved mucociliary epithelium containing microvilli and secretory granules, the latter having become more electron-lucent (Figures 2 and 3). Such a conversion of electron-dense into 


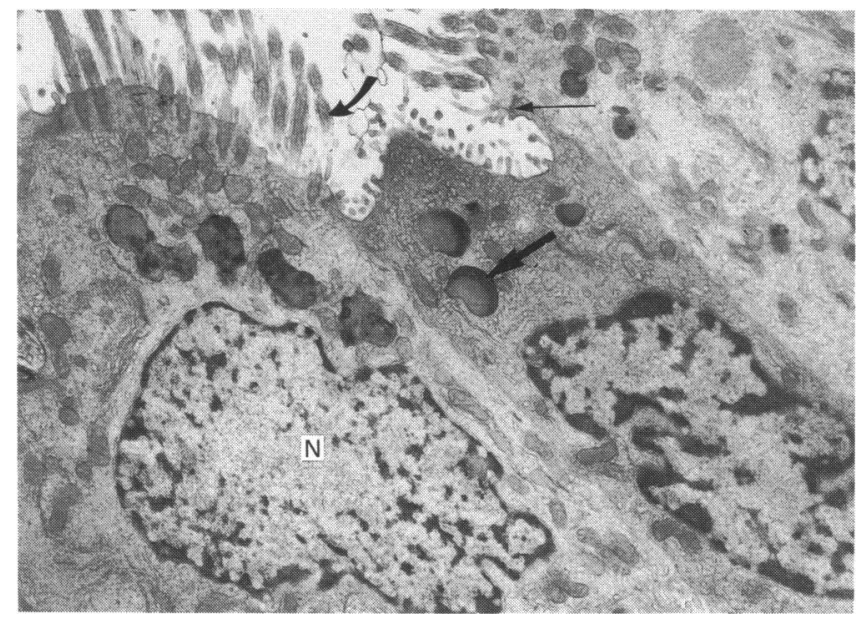

Figure 1 Transmission electron microscopy of normal rat trachea before incubation showing normal epithelium containing microvilli and apically localized granules

The tissue was prepared for microscopy as described in the Experimental section. Thick arrow, secretory granule; thin arrow, intercellular junction, curved arrow, cilia; $N$, nucleus. Magnification $\times 6240$.

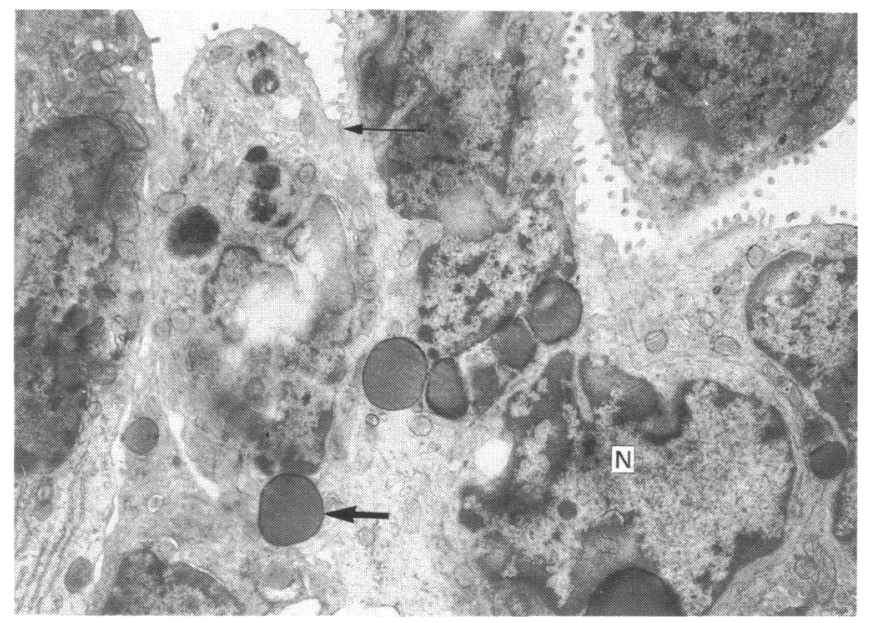

Figure 2 Transmission electron microscopy of rat tracheal epithelium after incubation for $96 \mathrm{~h}$ in a serum-free hormone-supplemented medium containing retinoic acid

Cells maintain their columnar morphology rather than that of the more cuboidal shape of squamous epithelial cells and also show prominent microvilli as well as apically localized granules. Thick arrow, secretory granule; thin arrow, intercellular junction; $N$, nucleus. Magnification $\times 6240$.

electron-lucent secretory granules has been observed in tracheas of rats exposed to irritants such as tobacco smoke (Lamb and Reid, 1969; Jeffrey and Reid, 1971; Coles et al., 1979).

Dot-blot hybridizating using an E-linked rat intestine mucin peptide tandem repeat probe, RMUC 176 (Gum et al., 1991), to total RNA isolated from rat trachea, intestine and colon showed a positive reaction (Figure 4a, blots $B-D$ ), but not with that of either liver (Figure 4a, blot $\mathrm{A}$ ) or alveolar region of the lung (Figure 4a, blot E). Yeast tRNA was used as a negative control (Figure 4a blot F). Hybridization with mouse type-I keratin probe, a marker for epithelial cells, to total RNA isolated from

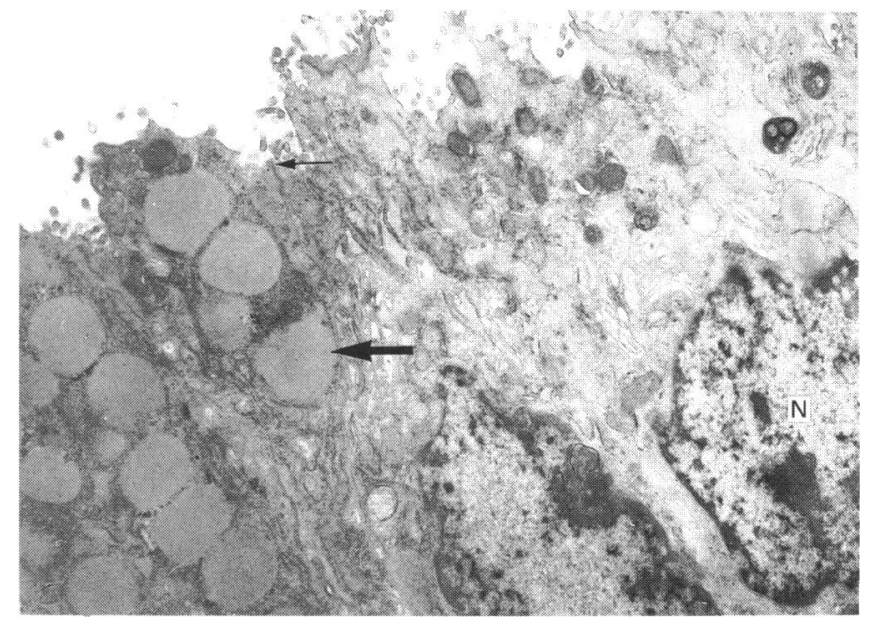

Figure 3 Transmission electron microscopy of rat tracheal epithelium after culture for $168 \mathrm{~h}$ in a serum-free hormone-supplemented medium containing retinoic acid showing microvilli and apically localized granules

Thick arrow, secretory granule; thin arrow, intercellular junction; N, nucleus Magnification $\times 6240$.

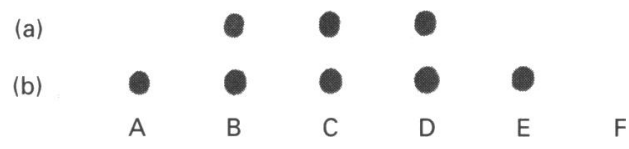

Figure 4 Dot-blot hybridization with E-linked rat intestine mucin probe of

Total RNA, blotted on Hybond membrane, was hybridized as described in the Experimental section. (a) blots $A-F$, liver, trachea, intestine, colon, alveolar region of the lung and yeast tRNA respectively, the latter being used as a negative control; (b) blots $A-E$, same as (a) except that total RNA was hybridized with rat $\beta$-actin probe.

tracheal explants grown at different periods of time in a medium with and without retinoic acid showed positive reaction (Figures $5 \mathrm{c}$ and $5 \mathrm{f}$, blots $\mathrm{A}-\mathrm{F}$ ), the results of which were similar to those observed in hamster tracheal epithelial cells (Edmondson and Mossman, 1991). Hybridization using the mucin probe to total RNA isolated from organ cultures grown at different periods of time in a medium containing retinoic acid showed positive signals in all of the preparations. Mucin mRNA was present in normal rat trachea at the baseline (Figure 5a, blot $\mathrm{A}$ ), and a prominent reaction was observed at all subsequent time points (Figure 5a, blots B-F). The level of $\beta$-actin message in these preparations is shown in Figure 5(b). In the absence of retinoic acid, however, the hybridization signal was positive at $24 \mathrm{~h}$ (Figure 5d, blot B) but barely visible at all subsequent time points (Figure 5d, blots $\mathrm{C}-\mathrm{F}$ ). $\beta$-Actin message level in these preparations is shown in Figure 5(e). Addition of retinoic acid to the latter culture at $96 \mathrm{~h}$ of growth induced mucin gene expression within $24 \mathrm{~h}$ (Figure $5 \mathrm{~g}$, blots $\mathrm{D}-\mathrm{F}$ ). $\beta$-Actin message in this culture is shown in Figure 5(h).

Agarose-gel ( $1 \%$ ) electrophoresis of the total RNA from rat tracheal organ culture at $96 \mathrm{~h}$ of growth showed a typical gel profile of $28 \mathrm{~S}$ and $18 \mathrm{~S} \mathrm{RNA}$ in the preparation (Figure 6a). Northern-blot hybridization of the total RNA, isolated from tracheal explants at 0,24 and $96 \mathrm{~h}$ of growth, to the rat intestine mucin probe and estimation of size by RNA markers $(0.24$ $9.5 \mathrm{~kb}$ ) showed a diffuse band ranging in approximate size from 


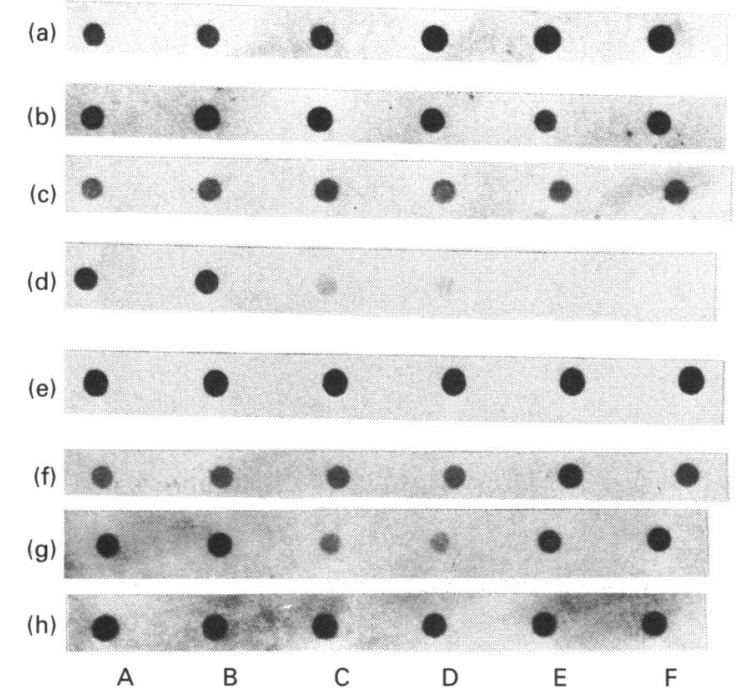

Figure 5 Dot-blot hybridization of total RNA from rat tracheal organ culture at different times of growth in a serum-free hormone-supplemented medium with or without retinoic acid

Hybridization with E-linked rat intestine mucin and type-l keratin probes was as described in the Experimental section. (a) Blots A-F, total RNA $(1.2 \mu \mathrm{g})$ from rat tracheal organ culture (+ retinoic acid) at $0,24,48,96,144$ and $192 \mathrm{~h}$ of growth probed with mucin probe; (b) same as (a) except that total RNA was hybridized with $\beta$-actin probe; (c) same as (a) except that total RNA $(0.8 \mu \mathrm{g})$ was hybridized with type-l keratin probe; (d) blots A-F, total RNA $(0.9 \mu \mathrm{g})$ from rat tracheal organ culture (without retinoic acid) at $0,24,48,96,144$ and $192 \mathrm{~h}$ of growth probed with mucin probe; (e) same as (d) except total RNA was hybridized with $\beta$-actin probe; (f) same as (d) except total RNA (0.8 $\mu$ g) was hybridized with type-I keratin probe; (g) same as (d) except that retinoic acid was added to the medium at $96 \mathrm{~h}$ of growth (blot $D$ ) and the culture was allowed to grow for another $24 \mathrm{~h}$ (blot E) and $48 \mathrm{~h}$ (blot F); (h) same as (f) except that total RNA was hybridized with $\beta$-actin probe.

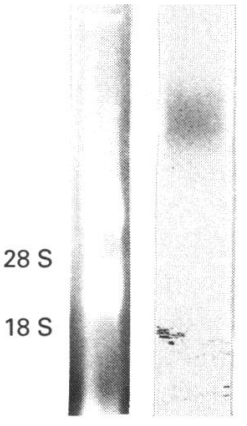

(a) (b)

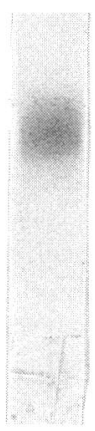

(c)

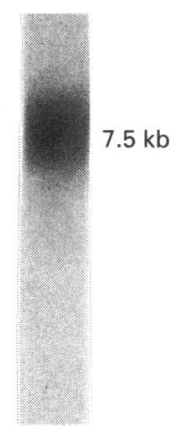

(d)
Figure 6 (a) Formaldehyde/agarose gel (1\%) electrophoresis of total RNA $(5 \mu \mathrm{g})$ from rat tracheal organ culture in a serum-free hormone-supplemented medium containing retinoic acid at $96 \mathrm{~h}$ of growth and (b, $c$ and d) RNA from the culture at 0, 24 and $96 \mathrm{~h}$ of growth transferred to the Hybond membrane and hybridized to E-linked rat intestinal mucin probe

Molecular mass was determined by the use of RNA standards.

7 to $8 \mathrm{~kb}$ (Figures $6 \mathrm{~b}$ and $6 \mathrm{~d}$ ). This diffuse pattern may in part be due to intrinsic polydisperity of the mucin message, as polydisperse mucin mRNAs have been noted previously in preparations from rat and human trachea and intestine (Gum et al., 1989; Gerard et al., 1990; Gum et al., 1991; Jany and

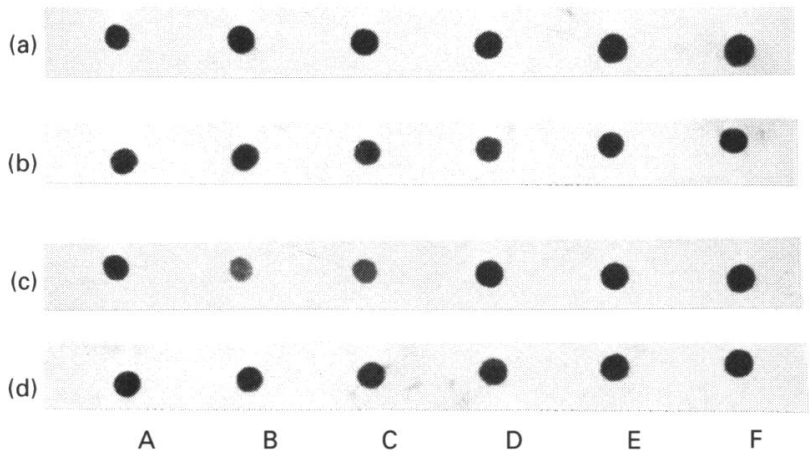

Figure 7 Effect of drugs on mucin gene expression in rat tracheal organ culture in serum-free hormone-supplemented medium containing retinoic acid

Total RNA $(0.9 \mu \mathrm{g})$ was blotted on Hybond membrane and the blot was hybridized with E-linked rat intestinal mucin probe. (a) Blot $\mathrm{A}$, control $(96 \mathrm{~h})$; blot $\mathrm{B}$, histamine $(100 \mu \mathrm{M})$; blot $\mathrm{C}$, methacholine $(100 \mu \mathrm{M})$; blot $\mathrm{D}$, phenylephrine $(100 \mu \mathrm{M})$; blot E, 8-bromocyclic AMP $(100 \mu \mathrm{M})$; blot F, 5-azacytidine $(0.6 \mu \mathrm{g} / \mathrm{ml})$; (b) same as (a) except that total RNA was hybridized with $\beta$-actin probe; (c) blot $\mathrm{A}$, control $(96 \mathrm{~h})$; blot $\mathrm{B}$, prednisolone $(100 \mu \mathrm{M})$; blot C, methacholine $(100 \mu \mathrm{M})+$ atropine $(100 \mu \mathrm{M})$; blot $\mathrm{D}$, atropine $(100 \mu \mathrm{M})$; blot E, pilocarpine $(100 \mu \mathrm{M})$; blot $\mathrm{F}$, isoprenaline $(100 \mu \mathrm{M})$; (d) same as (c) except that total RNA was hybridized with $\beta$-actin probe.

Basbaum, 1991; Porchet et al., 1991), porcine and ovine submaxillary gland (Timpte et al., 1988; Bhargava et al., 1990), human and mouse breast milk (Gendler et al., 1988; Spicer et al., 1991) and human pancreatic tumour (Lan et al., 1990), although partial degradation of these rather large molecules cannot be excluded.

Addition to the culture of histamine $(100 \mu \mathrm{M})$, methacholine $(100 \mu \mathrm{M})$, phenylephrine $(100 \mu \mathrm{M})$, 8-bromocyclic AMP $(100 \mu \mathrm{M}), 5$-azacytidine $(0.6 \mu \mathrm{g} / \mathrm{ml})$, methacholine $(100 \mu \mathrm{M})$ and atropine $(100 \mu \mathrm{M})$, atropine $(100 \mu \mathrm{M})$, pilocarpine $(100 \mu \mathrm{M})$ or isoprenaline $(100 \mu \mathrm{M})$ caused no dramatic stimulation or inhibition of the synthesis of mucin mRNA (Figure 7a, blots B-F; Figure 7c, blots C-F). Only the steroid prednisolone $(100 \mu \mathrm{M})$ had a definite inhibitory effect (Figure 7c, blot B).

\section{DISCUSSION}

This investigation was prompted by reports that isolated tracheal epithelial cells and organ cultures could be maintained with wellpreserved mucociliary epithelium for many weeks in a serum-free medium containing retinoids and that retinoids stimulate the synthesis of mucins (Marchok and Wasilenko, 1986; Wu, 1986; Rearick et al., 1987; Bhattacharyya et al., 1992). The rat tracheal organ culture system, as presented in this report, had wellpreserved epithelium with secretory granules and microvilli. Expression of keratin, a marker for epithelial cell differentiation, was observed in explants grown in a medium with and without retinoic acid. Dot-blot hybridization of total rat tracheal RNA against a rat intestine mucin probe, RMUC 176 (Gum et al., 1991), indicated that the trachea showed a strong basal level mucin gene expression throughout $192 \mathrm{~h}$ of incubation. However, in the absence of retinoic acid, mucin gene expression, although detected at $24 \mathrm{~h}$, was barely detectable thereafter. Addition of retinoic acid to the culture medium at $96 \mathrm{~h}$ of growth resulted in induction of mucin gene expression. Thus the mucin gene seems to be transcriptionally activated by retinoic acid. Jany et al. (1989) and Jany and Basbaum (1991) reported the absence of a signal when normal rat tracheal mRNA was hybridized with a 
human intestine mucin probe, SMUC 41 (Gum et al., 1989), and attributed their result to a lack of mucus cells (Plopper et al., 1983; Huang et al., 1989). However, mucin gene expression was induced in tracheas of rats exposed to $\mathrm{SO}_{2}$, which converted serous cells to mucus cells. An apparent lack of hybridization signal when normal rat tracheal RNA was incubated with the SMUC 41 probe and a strong reaction when incubated with the RMUC 176 probe may be due to the difference in sequence between these probes, as it has been reported that the sequence of cDNA from rat intestine (Gum et al., 1991) was very different from the two human intestine mucin cDNA sequences (Gum et al. 1989).

The results presented in this report regarding the effect of retinoic acid on mucin gene expression in rat tracheal organ culture are in agreement with those of Jany and Basbaum (1991), who suggested that induction of mucin gene activity is the primary event which leads to increased synthesis and secretion of mucins in tracheal epithelial cells from rats exposed to $\mathrm{SO}_{2}$. Retinoid-dependent gene regulation has previously been observed in squamous differentiation of tracheal epithelial cells (Smits et al., 1987). Additional studies will be necessary to determine whether retinoic acid also influences the production of mucin at the translation and post-translational glycosylation level. Another principal issue to be addressed in subsequent studies is whether retinoic acid-receptor complex directly regulates the mucin gene or induces a cascade of regulatory proteins, one or several of which regulates mucin gene expression.

In conclusion, the rat tracheal organ cultures, as described in this study, have been shown to express the mucin gene at their initiation, and their continued expression has been shown to vary according to the presence or absence of retinoic acid in the culture medium. These results suggest that differentiation and hence the induction of mucin gene expression by retinoic acid contribute to regulation of the synthesis of these important components. These findings have important implications in various respiratory diseases, such as asthma, cystic fibrosis and chronic bronchitis, which are characterized by oversecretion of mucus.

This work was supported in part by a grant (91MM508) from the United States Army Medical Research and Development Command. We are grateful to Dr. Manuel Schydlower, Chief of Clinical Investigation, for his encouragement and advice. We wish to thank Dr. Bruce Veit, Chief of Microbiology Section, for valuable comments regarding revision of the manuscript. We appreciate the assistance of Dr. Richard Harris, Chief of Biological Research Service, and his staff for providing tracheal samples. We thank Ms. Ann Tassmore for the electron microscopy service. We appreciate the editorial assistance provided by Ms. Vivian Maheu, Department of clinical Investigation. The opinions or assertions contained herein are the private views of the authors and are not to be construed as official or as reflecting the views of the Department of the Army or the Department of Defense.

\section{REFERENCES}

Bhargava, A. K., Woitach, J. T., Davidson, E. A. and Bhavanandan, V. P. (1990) Proc. Natl. Acad. Sci. U.S.A. 97, 6798-6802

Bhattacharyya, S. N., Ashbaugh, P., Lund, M. and Manna, B. (1992) Inflammation 16, 371-382

Chomczynski, P. and Sacchi, N. (1987) Anal. Biochem. 162, 156-159

Coles, S. J., Levine, L. R. and Reid, L. (1979) Am. J. Pathol. 94, 459-472

Davis, L. G., Dibner, M. D. and Battey, J. F. (1986) in Basic Methods in Molecular Biology, pp. 143-146, Elsevier, New York

Edmondson, S. W. and Mossman, B. T. (1991) Carcinogenesis 12, 679-684

Gendler, S., Taylor-Papadimitriou, J., Duhig, T., Rothbard, J. and Burchell, J. (1988) J. Biol. Chem. 263, 12820-12823

Gerard, C., Eddy, R. I. and Shows, T. B. (1990) J. Clin. Invest. 86, 1921-1927

Gum, J. R., Byrd, J. C., Hicks, J. W., Toribara, N. W., Lamport, D. T. A. and Kim, Y. (1989) J. Biol. Chem. 264, 6480-6487

Gum, J. R., Hicks, J. W., Lagace, R. E., Byrd, J. C., Toribara, N. W., Siddiki, B., Fearney, F. J., Lamport, D. T. A. and Kim, Y. (1991) J. Biol. Chem. 266, 22733-22738

Harris, C. C., Autrup, H., Stoner, G. D., McDowell, E. M., Trump, B. T. and Schafer, P. (1977) J. Natl. Cancer Inst. 59, 1401-1410

Huang, H. T., Haskell, A. and McDonald, D. M. (1989) Anat. Embryol. 180, 325-341

Jany, B. and Basbaum, C. B. (1991) Am. Rev. Respir. Dis. 144, S38-S41

Jany, B., Gallup, M., Gum, J., Kim, Y. and Basbaum, C. (1989) Am. Rev. Respir. Dis. 139, A367

Jeffrey, P. K. and Reid, L. (1971) J. Pathol. 133, 341-359

Krieg, T. M., Schafer, M. P., Cheng, C. K., Filpula, D., Flaherty, P., Steinert, P. M. and Roop, D. R. (1985) J. Biol. Chem. 260, 5867-5870

Lamb, D. and Reid, L. (1969) Br. Med. Bull. 1, 33-35

Lan, M. S., Batra, S. K., Qi, W.-N., Metzgar, R. S. and Hollingsworth, M. A. (1990) J. Biol. Chem. 265, 15294-15299

Marchok, A. C. and Wasilenko, W. J. (1986) in In Vitro Models of Respiratory Epithelium (Schiff, L. J., ed.), pp. 103-142, CRC Press, Boca Raton

Plopper, C. G., Mariassy, A. T., Wilson, D. W., Alley, J. L., Nishio, S. J. and Nettesheim, P. (1983) Exp. Lung Res. 5, 281-294

Porchet, N., Cong, N. V., Dufosse, J., Audie, J. P., Duperat, V. G., Gross, M. S., Dennis, C., Degand, P., Bernheim, A. and Aubert, J. P. (1991) Biochem. Biophys. Res. Commun. $175,414-422$

Rearick, J. I., Deas, M. and Jetten, A. M. (1987) Biochem. J. 242, 19-25

Smits, H. L., Floyd, E. E. and Jetten, A. M. (1987) Mol. Cell. Biol. 7, 4017-4023

Spicer, A. P., Parry, G., Patton, S. and Gendler, S. J. (1991) J. Biol. Chem. 266, 15099-15109

Timpte, C. S., Eckhardt, A. E., Abernathy, J. L. and Hill, R. L. (1988) J. Biol. Chem. 263, $1081-1088$

Wu, R. (1986) in In Vitro Models of Respiratory Epithelium (Schiff, L. J., ed.), pp. 1-26, CRC Press, Boca Raton 